\title{
Augmented Reality: A Review
}

\author{
${ }^{1}$ Amira B. Sallow, ${ }^{2}$ Younis Mohammed Younis \\ ${ }^{1}$ Department of Computer Science, Nawroz University, Duhok, Kurdistan Region - Iraq \\ ${ }^{2}$ Department of Computer Science, Faculty of Science, Zakho University, Duhok, Kurdistan Region - Iraq
}

\begin{abstract}
Accepting Augmented Reality (AR) technologies to add to our observation and assist our understanding, hearing, and touch our surroundings in novel and augmented habits. AR determination maintenance in playing field such as edification, preservation, proposal and investigation, to designation but a few. Designates the sports ground of AR, together with a momentary characterization and improvement olden times, the allowing knowledge and their physical appearance. It surveys the formal of the art by rereading about recent submissions of AR technology with some recognized margins on the subject of anthropological features in the use of AR methods that inventers will need to astound. In this paper, an AR technique is presented, as a review from 2017 until 2018. Furthermore, we have stated the best technique of AR, and table of summarization for all reviewed articles.
\end{abstract}

Keywords: Augmented Reality, games, Virtual Reality, 3D visualization, Smartphone.

\section{Introduction}

Augmented Reality (AR) is an unindustrialized technology with which a creature can do more than what another creature at same classification have not ability to feel that even by (see, hear, taste, touch or smelly) and this is what make different from another and this is what give ability to have a greater knowledge for specify location or things that another have no ability for that and by this technology it make human work easy by analysing the situation at the situation time or simultaneously or at the same time. The first AR system performed is a cinematographer, supposed that the motion pictures is an doings that have a duty to agree to an individual to act together with the surroundings by winning all the right mind in an in effect style.(Daponte et al., 2014)

Around year 1961 to 1962, specify researchers fashioned

Academic Journal of Nawroz University

(AJNU) Volume 8, No 3 (2019).

Regular research paper: Published 31 Aug 2019

Corresponding author's e-mail : amo_bibo@yahoo.com

Copyright (C2018 1Amira B. Sallow, ${ }^{2}$ Younis Mohammed

Younis. This is an open access article distributed under the

Creative Commons Attribution License. and original an emulator called Sensorium with photographs, reverberations, atmospheres, and fragrances. In this day and age, through the new early payment in microelectronics, an accumulative volume of AR arrangements and presentations are created. This knowledge is unattractive more rapidly to the operator because unfluctuating more transportable policies take part measuring device and devour doling out shows that allow to instrument AR systems. For instance, recent mobile phones have all the indispensable structures for a number of types of photographic $A R$ submissions: a cinematographic camera, an Internet piecing together, GPS, and Inertial-Quantity Component. All of this shows a developing concentration of the bazaar for equipment and presentations established on AR. For the application of AR arrangements, the dimensions of the user and bits and pieces situations have a necessary starring role. For this aim, once a momentary rough guide of these display place, the reputation of dimensions in the fundamental functionality of an AR system.(Daponte et al., 2014) 


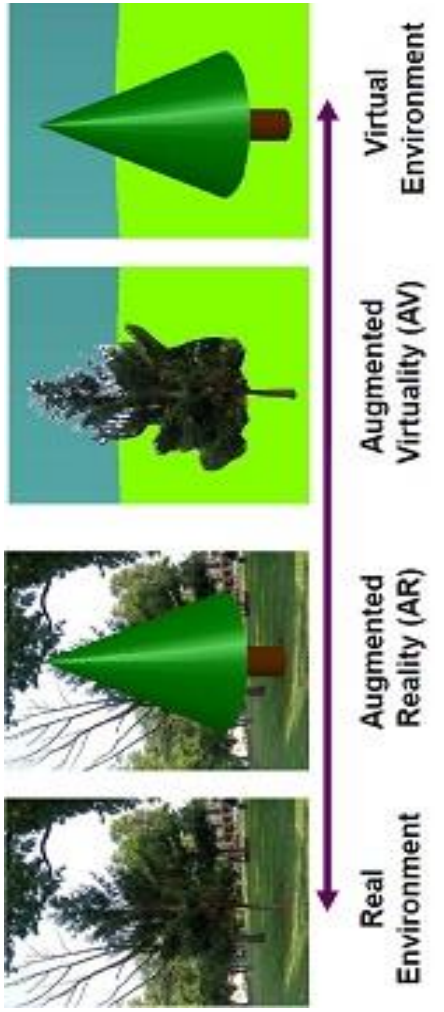

Fig. 1. Reality-Virtuality continuum

Description of AR structures established on the ideas of moving side by side and disingenuousness is open. On the source of the conveyance level, common arrangements can be on bad terms in two groupings, limited and secluded. A narrow organization is founded on somatic communications stuck between the manager and the neighboring background. A isolated organization is established on the entanglement of the employer in a cybernetic surroundings despite the fact that at the alike time the fleshly inducements from the foreign surroundings are let off. The play-acting apprehensions the side by side to which an surroundings is created on a computer-generated or on a non-existent flora and fauna. In a arrangement of communal solar system affording to conveyance and disingenuousness levels is offered. Equipment supplementary with the mental representativeness association both a local conveyance side by side and real surroundings. Computer-generated.(Daponte et al., 2014) Representativeness associations a out-of-the-way transference side by side by way of computer-generated surroundings. Tele being there associations a out-ofthe-way transference side by side with non-existent surroundings, despite the fact that AR associations a local transference side by side with fundamental surroundings. Visualise a knowhow by way of which you may possibly see supplementary than others see, make out supplementary than others pick up, and I don't know even hint, fragrance and discrimination equipment. What did you say if we had equipment to distinguish downright computational fundamentals and bits and pieces in the interior our tangible flora and fauna understanding, all-inclusive individuals and erections unfluctuating that support us in our per diem doings, while act together more or less reflexively over and done with mere gesticulations and communication?(Krevelen and Poelman, 2010)

By way of such machinery, ins and outs could see information I beg your pardon to do next when renovating an unfamiliar member of kit, medical practitioner may possibly see ultrasound examinations of body part while acting out surgical treatment on them, fire armed services could see office block arrangements to side-step or else too small to see exposures, defence force may possibly realize situations of competitor gunmen covered by unmanned inspection planes, and we may possibly spoke examinations for per capita eating place in the boulevard we're heavy-duty in, or encounter 10-foot elevated intelligent life form on the technique to work. $\mathrm{AR}$ is greater than before genuineness is this knowhow to form a "next age bracket, reality-based crossing point" and is heartrending from work room from one place to another the flora and fauna though about a number of work and purchaser market place. AR increments the material flora and fauna with fundamental (computer-generated) bits and pieces that 
give the impression to live together in the different astronomical as the non-existent domain.(Krevelen and Poelman, 2010)

In this study, we survey latest articles that show how $\mathrm{AR}$ affect to improve the commercial and also how to improve mobile phone depending on the utilized for make human life easy to understand. In addition to that, we considered the results that obtained after applying the technique to states and how effectively improve the action of issues more than other technique. The sections of this paper are ordered as follows: describing AR is presented in section 1 . Section 2 shows the literature review in different area for AR with their results. Lastly, Section 3 states conclusions.

\section{Literature review of classification in Intuition} detection System

This section will present the power and capability of using Classification in IDS. Many researchers in several domains have been worked successfully with it, which represented as following below:

(Mourtzis, Zogopoulos and Vlachou, 2017) Conservation of industrial products is in the middle of the furthermost shared service station in productiveness and its cost over and over again go above $30 \%$ of the in-service costs. The boss unbiased of their effort is to advance a cloud-based examination inclined towards course of action that hardware AR gear for out of reach taking care of by qualifying shared guide among the on promotion talented laborer and the producer.In this paper They presented the development and testing of an Augmented Reality remote maintenance platform that can be used for providing Products- Service Systems (PSS) maintenance service. A cloud platform was also implemented as a communication enabler and to assist existing knowledge reuse. Future work could focus on integrating the existing system and other systems in an enterprise, increasing interoperability.

(Danielsson et al., 2017)There are two purposes researchers are included to this research: to calculate if protestors can mimic human-robot teamwork and to measure if AR-based borders can leader test-persons over association. Initial one, protestors can be scrounge deal to make a connected examination circumstance that lets a test-individual to accomplish genuine gathering in collaboration with a robot. The outcomes from the exploratory instruction were uneven since the test-people had their gentries slow them when utilized. Despite this they achieved to go completed every one of the means of the charges. In view of this one might say that the protestor has touched a level of adulthood that permit people groups denied of past gathering information to independently work over every one of the stepping stools of the supporter. Second one. In any case, the amount of mistakes when utilized confidently is excessively through and through to be agreeable. The amount of errors exhibits that the party is multifaceted adequate to require summons. So the undertaking in the protestor is of a maintaining trouble however the headings should be vague. The overhang exhibits a most noteworthy perspective of the get together zone and is along these lines constrained in how directions can be appeared.

(Erkoyuncu et al., 2017) The considered the authentication has unproven that ARAUM (Augmented Reality Authoring for Maintenance) can recover the good organization in showing looking after. The main aids of the paper, interconnected to looking after good organization and AR fields, include: Humanizing maintainer good organization with adaptive data super vision: ARAUM underwrites to authoring exploration by submission an advanced organization for the evidence needs of AR authoring tools, and a new technique to by design form put over 
moving picture in real-time. Non-programmers have ability to make AR at ease: ARAUM's Authoring Display place diminutions the possessions looked-for to improve AR-animated at ease. ARAUM's Authoring Display place diminutions the possessions looked-for to improve AR-animated at ease. Strategy of environment responsiveness building block: The CDF (Context Data Framework) and the CAM (Context-Awareness Module) proposition a new line of attack for AR environment responsiveness.

(Pryss et al., 2017)Mobile augmented reality submissions establish an instance for user support that is comfortable in these circumstances. In the Augmented Reality Motor Submission venture, specialists are industrialized a piece that permits refined position constructed versatile expanded reality entries. At the asking of this piece, various improvements were appreciated. In a considerable measure of these assignments, an element to qualify pathways was press for. Courses, for example, May commitment controllers out of sight of manufactured climbing. To show the concert of the industrialized procedure, also results of an experimentation are obtainable.

(Shan et al., 2017)They are contemporaneous an augmented reality organization for mobile procedures that helps 3D brain malignant tumor positive thinking in real period. The course of action utilizes excellence treatment highlights to pathway the issue in the segment. The course of action complete camera alteration based on the appearance size of the concentration, as an option of the common technique of expending various chessboard pictures to bring into line the camera each and every period the accommodation is settled on another gadget. Camera 3D attitude educated guess is completed by outcome its situation and coordination based on a set of 3D arguments and their conforming 2D prognostications. Conferring to the predictable camera attitude, a reassembled brain malignant tumor prototypical is demonstrated at the same position as the question's real structure. The results of their experimentation confirmation the arrangement was positive in carrying out the brain malignant tumor intensification in real period with a projection accuracy more than $95 \%$.

(Stoltz et al., 2017)They are exploring the openings get to your feet from the tradition of augmented reality in warehouses as well as the barricades for its manufacturing taking on. This is completed via a sequences of general practitioner conferences and via an experimentation premeditated using Google Glass. There results point toward that unfluctuating among the knowledge is not complete enough at the moment, the probable reimbursements it can offer make it encouraging for the neighboring yet to come.

(Michel et al., 2018)They are explored the utilizing of approach approximation algorithms in the specific situation of pedestrians via product mobile phone. Researchers are suggested a target for calculating and likening the accuracy of approach approximations through usual mobile phone signals without and using charming alarms. At the begging in their tests direct the light on the qualified effects of standardizations, limits, sounds, unfairness, signals, charming alarms, and selection rates at the time of approximating approach on mobile phone. After that the particular setting of approach approximation through augmented reality signals. In all circumstances, they commend creators to utilize practice standardization and processes in extra of those providing by mobile's OS. Their process "Michelob" offers important improvements in accuracy when approximating approach in the occurrence of charming alarms.

(Grabowski, Rowen and Rancy, 2018)Novel expertise in 
care-precarious systems proposal the capacity of following group system landscapes and abilities; logical analytics; improved and distant checking; and possibly upgraded machinist presentation. But problems rise almost the effect of such skills on organization care, machinist presentation, and choice methods, in situations where anodyne and real presentation are of supreme reputation. Wearable, immersive augmented reality (WIAR) knowledge is one such knowledge whose overview catalysts these problems. Notwithstanding the propagation of WIAR knowledge in care-precarious systems, small number of educations have studied its effects on machinist presentation, choice methods and state consciousness in these situations. As a result, researchers are reflecting research needs for estimating WIAR knowledge in careprecarious systems. To prove the research needed, they reflect the utilizing case of a WIAR knowledge in marine navigation, and proposition a research context, brief research needs and classifying needed following periods.

(Chu, Matthews and Love, 2018)Augmented Reality (AR) takes stayed future as a device to improve the procedure of material abstraction from structure material representations to progress the competence and success of operatives' jobs. However, there is incomplete study that has assessed the success and usability of AR in this domain. This research purposes to report this hole and estimate the success of BIM and AR system mixing to improve task competence through successful the material repossession procedure through structure. To reach this, a project science research method was accepted that allowed the growth and presentation of a mobile BIM AR system (manufactured article) with cloud-based storage abilities to be tried and estimated using a transportable desktop experimentation. A total of 20 members likened current physical material recovery systems (control group), with material recovery over the object (non-control group). The results open that the applicants using the object were almost 50\% quicker in finishing their experimentation tasks, and stanch fewer errors, when equaled to the control group. This research establishes that a slight alteration to current material setups (2D plans) with the presence of Quick Reply indicators can meaningfully recover the material recovery procedure and that BIM and AR addition has the possible to improve task effectiveness.

(Mota et al., 2018)Visual Environment for Planning Communicating Knowledge Situations, a visual device for planning, modifying and organizing knowledge equipment, offers teachers with an improvement surroundings with a low admittance starting point. In advance convenient gadgets are outfitted with radars and have fundamental handling charge to using increased reality gear. Despite the profound utilization of convenient gadgets in students' lives, the utilization of increased reality compact entries as training actualizes isn't restricted amidst teachers. The in advance work benevolences a back ground comprise of the de-elopement gadget and a method for candid and set up book learning achievements. It resolve on the enlarged reality instruments of the composing devices, which face clients to make their own portable expanded reality training applications. It additionally contemporaneous the consequences of the evaluation of the back ground with 47 third-level educationalists, and two condition investigations of address theater putting into routine with regards to convenient increased reality applications industrialized by these educators. The results demonstrate the appropriateness of the back ground and authoring implement for auxiliary users without software development skills in unindustrialized their own application. 
2.1 Summary

to test each domain with short description are

A summary of the previously above-mentioned illustrated in the table below:

researches includes data (technique) that has been used

Table (1) Summary

\begin{tabular}{|c|c|c|c|c|}
\hline $\begin{array}{l}\text { Authors and } \\
\text { year of pub. }\end{array}$ & $\begin{array}{c}\text { Problem } \\
\text { domain }\end{array}$ & Data & Disadvantage & Short description \\
\hline $\begin{array}{l}\text { (Stoltz et al., } \\
\text { 2017) }\end{array}$ & $\begin{array}{l}\text { improve the } \\
\text { performance of } \\
\text { warehouse } \\
\text { operations }\end{array}$ & $\begin{array}{l}\text { academia and } \\
\text { industry }\end{array}$ & $\begin{array}{l}\text { Using on product and results are only } \\
\text { according to this product only. }\end{array}$ & $\begin{array}{l}\text { This is completed via a sequences of general practitioner } \\
\text { conferences and via an experimentation premeditated } \\
\text { using Google Glass. }\end{array}$ \\
\hline $\begin{array}{l}\text { (Shan } \text { et al., } \\
2017)\end{array}$ & $\begin{array}{l}\text { performs } \\
\text { camera } \\
\text { calibration }\end{array}$ & $\begin{array}{l}\text { number of } \\
\text { chessboard } \\
\text { images }\end{array}$ & $\begin{array}{l}\text { Here they got the very good result but } \\
\text { with ignoring the only one disadvantage } \\
\text { that is time consumption. }\end{array}$ & $\begin{array}{l}\text { Camera 3D attitude educated guess is completed by } \\
\text { outcome its situation and coordination based on a set of } \\
\text { 3D arguments and their conforming 2D prognostications. }\end{array}$ \\
\hline $\begin{array}{l}\text { (Danielsson } \text { et } \\
\text { al., 2017) }\end{array}$ & $\begin{array}{l}\text { tight human- } \\
\text { robot } \\
\text { collaboration }\end{array}$ & $\begin{array}{l}\text { humans and } \\
\text { robots work } \\
\text { directly }\end{array}$ & $\begin{array}{l}\text { There current results have not given } \\
\text { specific insight up-to-the-minute how } \\
\text { dissimilar proposals have emotional } \\
\text { impact the presentation of test-persons } \\
\text { it has given legitimacy to the method of } \\
\text { using protestors to test assembly- } \\
\text { instructions. }\end{array}$ & $\begin{array}{l}\text { Based on this it can be said that the protestor has touched } \\
\text { a level of adulthood that allow peoples deprived of } \\
\text { previous meeting knowledge to self-sufficiently work } \\
\text { over all the ladders of the supporter. }\end{array}$ \\
\hline $\begin{array}{l}\text { (Erkoyuncu et } \\
\text { al., 2017) }\end{array}$ & $\begin{array}{l}\text { improve the } \\
\text { maintenance } \\
\text { efficiency }\end{array}$ & $\begin{array}{l}\text { context aware } \\
\text { Augmented } \\
\text { Reality (AR) }\end{array}$ & $\begin{array}{l}\text { Their Strategy of environment } \\
\text { responsiveness building block offer a } \\
\text { new line of attack for AR environment } \\
\text { responsiveness. }\end{array}$ & $\begin{array}{l}\text { interconnected to looking after good organization and AR } \\
\text { fields, include: Humanizing maintainer good organization } \\
\text { with adaptive data super vision: ARAUM underwrites to } \\
\text { authoring exploration by submission an advanced } \\
\text { organization for the evidence needs of AR authoring } \\
\text { tools, and a new technique to by design form put over } \\
\text { moving picture in real-time. }\end{array}$ \\
\hline $\begin{array}{l}\text { (Pryss et al., } \\
\text { 2017) }\end{array}$ & $\begin{array}{l}\text { Interestingly, } \\
\text { more and more } \\
\text { users crave for } \\
\text { mobile } \\
\text { assistance in } \\
\text { their leisure } \\
\text { time. }\end{array}$ & $\begin{array}{l}\text { Mobile AR } \\
\text { applications }\end{array}$ & $\begin{array}{l}\text { The change of an ARES method that } \\
\text { qualifies roadway supervision have } \\
\text { need of novel impressions that are not } \\
\text { possible in this paper. }\end{array}$ & $\begin{array}{l}\text { In the Augmented Reality Engine Submission project, } \\
\text { researchers are industrialized a kernel that allows refined } \\
\text { position built mobile augmented reality submissions. At } \\
\text { the begging of this kernel, a number of developments } \\
\text { were comprehended. }\end{array}$ \\
\hline $\begin{array}{l}\text { (Mourtzis, } \\
\text { Zogopoulos } \\
\text { and Vlachou, } \\
\text { 2017) }\end{array}$ & $\begin{array}{l}\text { combined } \\
\text { ecosystem of } \\
\text { Products- } \\
\text { Service } \\
\text { Systems } \\
\end{array}$ & $\begin{array}{l}\text { remote } \\
\text { maintenance by } \\
\text { enabling } \\
\text { cooperation }\end{array}$ & $\begin{array}{l}\text { Here because of using the cloud it will } \\
\text { be less cost than another servers } \\
\text { system, but very and very less security } \\
\text { than servers system. }\end{array}$ & $\begin{array}{l}\text { The chief impartial of their exertion is to progress a } \\
\text { cloud-based examination slanted towards arrangement } \\
\text { that equipment AR equipment for inaccessible looking } \\
\text { after by qualifying mutual aid among the on } \\
\text { advertisement skilled worker and the maker. }\end{array}$ \\
\hline $\begin{array}{l}\text { (Chu, } \\
\text { Matthews and } \\
\text { Love, 2018) }\end{array}$ & $\begin{array}{l}\text { support } \\
\text { information } \\
\text { structuring and } \\
\text { exchange }\end{array}$ & $\begin{array}{l}\text { centralization of } \\
\text { information }\end{array}$ & $\begin{array}{l}\text { Their Results showed that the } \\
\text { applicants using the object were almost } \\
50 \% \text { quicker in finishing their } \\
\text { experimentation tasks from another } \\
\text { researches. But can't finding results } \\
\text { without errors. }\end{array}$ & $\begin{array}{l}\text { There is incomplete study that has assessed the success } \\
\text { and usability of AR in this domain. This research } \\
\text { purposes to report this hole and estimate the success of } \\
\text { BIM and AR system mixing to improve task competence } \\
\text { through successful the material repossession procedure } \\
\text { through structure. }\end{array}$ \\
\hline $\begin{array}{l}\text { (Michel } \text { et al., } \\
\text { 2018) }\end{array}$ & $\begin{array}{l}\text { pedestrian } \\
\text { navigation }\end{array}$ & $\begin{array}{l}\text { magnetic } \\
\text { sensors }\end{array}$ & $\begin{array}{l}\text { The disadvantage here is cost of } \\
\text { material as well as tools that utilized to } \\
\text { produce a qualified sensor for alarm. }\end{array}$ & $\begin{array}{l}\text { At the begging in their tests direct the light on the } \\
\text { qualified effects of standardizations, limits, sounds, } \\
\text { unfairness, signals, charming alarms, and selection rates } \\
\text { at the time of approximating approach on mobile phone. } \\
\text { After that the particular setting of approach } \\
\text { approximation through augmented reality signals. }\end{array}$ \\
\hline $\begin{array}{l}\text { (Mota } \text { et al., } \\
\text { 2018) }\end{array}$ & $\begin{array}{l}\text { engagement of } \\
\text { teachers }\end{array}$ & $\begin{array}{l}\text { visual tool for } \\
\text { designing }\end{array}$ & $\begin{array}{l}\text { It will be a joyful that mixing the } \\
\text { technology to education as well as } \\
\text { helpful for both teacher and student to } \\
\text { learn and get more in formation for } \\
\text { specific subject but in my opinion the } \\
\text { disadvantage will be how much it be } \\
\text { acceptable to users than any other } \\
\text { installed app or game, here my } \\
\text { suggestion is mixing AR game to } \\
\text { education to not make students boring. }\end{array}$ & $\begin{array}{l}\text { In progress portable devices are armed with radars and } \\
\text { have necessary processing command to utilizing } \\
\text { augmented reality equipment. In the face of the weighty } \\
\text { use of portable devices in undergraduates' lives, the use } \\
\text { of augmented reality portable submissions as education } \\
\text { implements is not limited in the middle of educators. }\end{array}$ \\
\hline $\begin{array}{l}\text { (Grabowski, } \\
\text { Rowen and } \\
\text { Rancy, 2018) }\end{array}$ & $\begin{array}{l}\text { predictive } \\
\text { analytics }\end{array}$ & $\begin{array}{l}\text { technologies on } \\
\text { system safety }\end{array}$ & $\begin{array}{l}\text { User should all time borrow with } \\
\text { him/her a kit to give and get the } \\
\text { approximately result. }\end{array}$ & $\begin{array}{l}\text { Wearable, immersive augmented reality (WIAR) } \\
\text { knowledge is one such knowledge whose overview } \\
\text { catalysts these problems. Notwithstanding the propagation } \\
\text { of WIAR knowledge in care-precarious systems, small } \\
\text { number of educations have studied its effects on } \\
\text { machinist presentation, choice methods and state } \\
\text { consciousness in these situations. As a result, researchers } \\
\text { are reflects research needs for estimating WIAR } \\
\text { knowledge in care-precarious systems. }\end{array}$ \\
\hline
\end{tabular}




\section{Conclusion}

Currently, the AR is pleasant extra available because of the progresses in microelectronics and the importance of the bazaar to smartphone systems. In this study, we introduce the main idea of $\mathrm{AR}$ and review the latest article that used of this innovation in mobile phone system in different domains and we have presented their weaknesses. As a deduction, this review shows that AR has appealed properties and high effective when applied to mobile phone in diverse domains, especially in internet network and security field and presented its features, discussed some of the shortcomings that they are facing and outlined some of their disadvantages. Moreover, the study indicates that $\mathrm{AR}$ improves the results and the performances when it's compared to another computable technique or without mobile phone $\mathrm{AR}$ and have become an effective platform for the exploration of interaction and collaboration.

\section{References}

1. Chu, M., Matthews, J. and Love, P. E. D. (2018) 'Integrating mobile Building Information Modelling and Augmented Reality systems: An experimental study', Automation in Construction. Elsevier, 85(February 2017), pp. 305-316. doi: 10.1016/j.autcon.2017.10.032.

2. Danielsson, O. et al. (2017) 'Assessing Instructions in Augmented Reality for Human-robot Collaborative Assembly by Using Demonstrators', Procedia CIRP. Elsevier B.V., 63, pp. 89-94. doi: 10.1016/j.procir.2017.02.038.

3. Daponte, P. et al. (2014) 'State of the art and future developments of the Augmented Reality for measurement applications', Measurement: Journal of the International Measurement Confederation. Elsevier Ltd, 57, pp. 53-70. doi: 10.1016/j.measurement.2014.07.009.

4. Erkoyuncu, J. A. et al. (2017) 'Improving efficiency of industrial maintenance with context aware adaptive authoring in augmented reality', CIRP Annals Manufacturing Technology, 66(1), pp. 465-468. doi: 10.1016/j.cirp.2017.04.006.

5. Grabowski, M., Rowen, A. and Rancy, J. P. (2018) 'Evaluation of wearable immersive augmented reality technology in safety-critical systems', Safety Science. Elsevier, 103(November 2017), pp. 23-32. doi: 10.1016/j.ssci.2017.11.013.

6. Krevelen, D. W. F. van and Poelman, R. (2010) 'A Survey of Augmented Reality Technologies, Applications and Limittions', The International Journal of Virtual Reality, 9(2), pp. 1-20. doi: 10.1155/2011/721827.

7. Michel, T. et al. (2018) 'Attitude estimation for indoor navigation and augmented reality with smartphones', Pervasive and Mobile Computing, 46, pp. 96-121. doi: 10.1016/j.pmcj.2018.03.004.

8. Mota, J. M. et al. (2018) 'Augmented reality mobile app development for all', Computers and Electrical Engineering, 65, pp. 250-260. doi: 10.1016/j.compeleceng.2017.08.025.

9. Mourtzis, D., Zogopoulos, V. and Vlachou, E. (2017) 'Augmented Reality Application to Support Remote Maintenance as a Service in the Robotics Industry', Procedia CIRP. The Author(s), 63, pp. 46-51. doi: 10.1016/j.procir.2017.03.154.

10. Pryss, R. et al. (2017) 'Enabling Tracks in LocationBased Smart Mobile Augmented Reality Applications', Procedia Computer Science. Elsevier B.V., 110, pp. 207-214. doi: 10.1016/j.procs.2017.06.086.

11.Shan, Q. et al. (2017) 'Augmented Reality Based Brain Tumor 3D Visualization', Procedia Computer Science. Elsevier B.V., 113, pp. 400-407. doi: 10.1016/j.procs.2017.08.356.

12.Stoltz, M.-H. et al. (2017) 'Augmented Reality in Warehouse Operations: Opportunities and Barriers', IFAC-PapersOnLine. Elsevier B.V., 50(1), pp. 1297912984. doi: 10.1016/j.ifacol.2017.08.1807. 